\title{
Testing of Real Exchange Rate - Real Interest Rate Differential Relationship in Serbia-EMU Case $^{2}$
}

\author{
Article history \\ Received: 24 July 2013 \\ Sent for revision: 11 September 2013 \\ Received in revised form: 28 November 2013 \\ Accepted: 29 November 2013 \\ Available online: 6 December 2013
}

\begin{abstract}
The goal of this study is to investigate whether there are empirical proofs for sustainability of real exchange rate - real interest rate differential relation in Serbia - EMU case for the period between January 2007 and May 2012. Theoretical relation has been derived by combining uncovered interest rate parity and Fisher equation, while empirical testing has been based on time series cointegration concept and application of Johansen and EngleGranger cointegration test. The findings obtained have shown that real exchange rate index and real interest rate differential are not cointegrated series, i.e. that there is no long-run equilibrium relation between them. Based on such findings, it can be concluded that there are no empirical proofs that real exchange rate - real interest rate differential relation is a key to explain longterm dynamics of RSD/EUR real exchange rate.
\end{abstract}

Keywords: real exchange rate, real interest rate differential, uncovered interest rate parity, Fisher equation, time series cointegration.

\section{Testiranje relacije realni devizni kurs-diferencijal realnih kamatnih stopa u slučaju Srbija-EMU}

Apstrakt: Cilj ove studije jeste da se ispita da li postoje dokazi empirijske održivosti relacije realni devizni kurs - diferencijal realnih kamatnih stopa $u$ slučaju Srbije i EMU za period od januara 2007. do maja 2012. godine. Teorijska veza izvedena je kombinovanjem nepokrivenog pariteta kamatnih stopa $i$

\footnotetext{
${ }^{1}$ Institute of Social Sciences, ppetrovic@idn.org.rs.

${ }^{2}$ The paper presents the results of a study conducted as part of the project III47010: funded by the Ministry of Education, Science and Technological Development, Republic of Serbia, 2011-2014.
} 
Petrović P.: Testing of real exchange rate - real interest rate differential relationship...

Fišerove jednačine, dok je empirijsko testiranje zasnovano na konceptu kointegracije vremenskih serija i primeni Johansenovog i Engl-Grejndžerovog testa. Rezultati do kojih smo došli pokazuju da indeks realnog deviznog kursa $i$ diferencijal realnih kamatnih stopa nisu kointegrisane serije, odnosno da one ne formiraju dugoročnu ravnotežnu relaciju. Na osnovu ovakvih nalaza zaključujemo da ne postoje empirijski dokazi da relacija realni devizni kurs diferencijal realnih kamatnih stopa predstavlja ključ za objašnjenje dugoročne dinamike realnog kursa dinara prema evru.

Ključne reči: realni devizni kurs, diferencijal realnih kamatnih stopa, nepokriveni paritet kamatnih stopa, Fišerova jednačina, kointegracija vremenskih serija.

\section{Introduction}

Real exchange rate - real interest rate differential relationship has been a kind of doubt and controversy in international finance literature for long time now. Although this connection is theoretically based on popular theories and models of real exchange rate determination (Dornbusch, 1976; Frenkel, 1976), the findings obtained in empirical researches are quite diverse and contradictory.

Campbell and Clarida (1987) were researching the connection between the real exchange rate, real interest rate differentials and long-run equilibrium real exchange rate. By using a state-space approach, the authors analysed how much the changes in real exchange rate can be attributed to movements of real interest rate differentials, and how much to the changes of long-run equilibrium real exchange rate, in particular for the U.S., Canadian, British, German and Japanese data from October 1979 to March 1986. The results have shown that dynamics of real exchange rate for dollar is primarily determined by unanticipated changes of the expected long-run real exchange rate, while variations of the real interest rates differentials are not enough to be accounted for a significant part of real exchange rate volatility.

Meese and Rogoff (1988), by analysing data for United States, Germany, Japan, and the United Kingdom, discovered that relation between the real exchange rate and real interest rates differential has theoretically expected sign, but it is not statistically significant, so real interest rates differential cannot be reliably used for the forecast of real exchange rate. Meese and Rogoff (1988) stated the significance of real shocks as one of possible explanations why monetary models are quite unsuccessful in explaining the real exchange rate dynamics. Actually, it cannot be expected that monetary models, primarily focused on monetary shocks, have significant explanatory power. The assumption of the significance of real shocks (such as productivity shocks) deserves far greater attention from researchers, although it is still unclear 
Petrović P.: Testing of real exchange rate - real interest rate differential relationship...

whether it will be helpful in designing of better exchange rate empirical models. Key difficulties are seen in the fact that it is very difficult to notice which real factors (shocks) affect the real exchange rate in certain periods.

In addition, Edison and Pauls (1991) made efforts to reveal if there was a systematic relation between the real exchange rate and real interest rate differential, and if there was, which form of dependence has grounds in empirical data. As in many other papers, Edison and Pauls, using techniques of time series cointegration, did not succeed in revealing empirically based proofs of the real exchange rate - real interest rate differential relation existence. The analysis results have shown that series of the real interest rate differential, and its constitutive components - nominal interest rate differential and inflation differential, are not cointegrated with the real exchange rate. The conclusion does not change even if alternative measures of the expected inflation and data for different periods are applied. Therefore, application of standard econometric cointegration techniques does not confirm the empirical relation between the real exchange rate and real interest rate differential. Although the authors checked the robustness of results with regard to: different exchange rate concepts, changes in researching periods, different interest rate concepts, different inflation measures necessary for structuring of real interest rates, their recommendation for further researches pertains to the need of using newer and more reliable cointegration tests which enable estimation of more than one cointegration vector.

Besides, it is worthy to mention that Clarida and Gali (1994, pp. 7-14) had developed a mathematical model based on which they concluded that there was significant deviation of the real exchange rate from the real interest rate differential. Similar findings were obtained by Engel and Kim (1999, pp. 348351) by testing cointegration between the permanent component of the U.K./U.S real exchange rate and the U.K./U.S real interest rate differential.

Certain contrast to the above presented findings are those offered by Chortareas and Driver (2001) in their study for 17 OECD countries. Application of cointegration techniques to panel data indicated the existence of long-run equilibrium relation between the real exchange rate and real interest rate differential. Yet, division of the sample to small open economies and G7 countries leads to a conclusion that the second case does not contain proofs on the existence of the observed relation. According to the authors' opinion, this can be the explanation why previous studies, dominantly focused on G7 countries, did not succeed in revealing the connection between the exchange rate and interest rate differential.

Mixed results were obtained in Edison and Melick's (1999) study, where real exchange rate - real interest rate relation was empirically tested by three methodological frameworks applied to four national currencies and two time horizons covering the period longer than 20 years. The findings revealed 
Petrović P.: Testing of real exchange rate - real interest rate differential relationship...

moderate proofs about the existence of the observed relation in a long period, which does not refer to short term. The existence of this relation is most obvious in the case of real effective exchange rate of the US dollar.

Existence of the relationship was also noticed by MacDonald and Nagayasu (1999) by assessing the long-run equilibrium equation between real exchange rate and real interest rate differential using panel cointegration techniques on a sample of 14 industrialised countries. According to MacDonald and Nagayasu's opinion, failure of other economists to find empirical proofs about the existence of this connection is far more related with econometric techniques they used than with lacks of theoretical models.

Empirical proofs of the U.K./U.S real exchange rate - real interest rate differential connection existence, but in the context of their volatility regime, were offered by Kanas (2005). The existence of relation in terms of mutual dependence of volatility regime means that volatility regime of the real exchange rate depends on the volatility regime of real interest rate differential. The results of this study showed that regime of nominal exchange rate influences both volatility regimes (real exchange rate and interest differential) by establishing the link that connects them. In other words, in the period of floating (fixed) exchange rates, both variables express high (low) volatility, which quite reliably shows that key driving force hidden behind the connection of volatility regimes is actually the regime of nominal exchange rate. According to these findings, in order to overcome the gap between theoretical mathematical models and numerous empirical studies it is very important to bear in mind the nominal exchange rate regime.

Certain proofs of the observed relation existence were obtained by Baxter (1994). The results of his research showed that there are empirical grounds for the real exchange rate - real interest rate differential relation with the strongest link at trend and business-cycle frequencies. There is no relationship between these variables at high frequencies (Baxter, 1994, p. 35). Researching the basic building blocks of theoretical relation between the observed variables, primarily hypotheses of uncovered interest parity and ex ante purchasing power parity, it was established that empirical grounds to these theories are very moderate. This is why Baxter (1994), abandoning the previous theories, developed a model suggesting the relation between the temporary component of real exchange rates and the real interest differential. The analysis indicated the existence of proofs that real interest differential is positively correlated with real exchange rates, but real interest differentials do not explain a great deal of the variance in the temporary components of real exchange rates (Baxter, 1994, p. 35). Since real interest differentials related only to the temporary component of real exchange rates, and bearing in mind that greatest part of real exchange rates variations pertains to its permanent 
Petrović P.: Testing of real exchange rate - real interest rate differential relationship...

component, it is clear why the connection between real interest differentials and real exchange rates is very weak in many studies.

Byrne and Nagayasu (2010) discovered statistically significant long-run equilibrium relationship between the UK/US real exchange rate and the real interest rate differential using recent econometric methods robust to potential structural breaks. Use of standard cointegration techniques which do not take into account potential structural breaks confirmed the results obtained in numerous previous studies - the observed relation does not exist at all. Yet, application of newer tests robust to structural breaks showed that real interest rate differential is an important determinant of the real exchange rate. Research extension to 12 additional, mainly European, countries suggested that presence of structural breaks is not common for all countries, but is mainly country-specific.

Nakagawa (2002) also managed to estimate the observed relation taking into account the nonlinear adjustment in real exchange rates, which was not the case with previous analyses. Actually, it was shown in this paper that introduction of nonlinearity into the traditional model confirms the existence of the real exchange rate - real interest rate differential relationship.

Detailed overview of different empirical approaches to the observed phenomenon analysis can be seen in Chapter 2 of James, Marsh and Sarno (2012).

Our research, results of which are presented in this paper, is dedicated to the analysis of empirical sustainability of real exchange rate index - real interest rate differential connection between Serbia and European Monetary Union (EMU). Following the known mathematical model, a baseline hypothesis has been formulated stating that empirical data confirms the presence of real exchange rate index - real interest rate differential relationship in Serbia-EMU case.

The paper consist of six parts. The introduction contains an overview of most important papers which analysed the observed relationship. The second and third part included methodological framework for the research and basic information about data used during the analysis. Fourth part includes the results of the empirical research and fifth one the most important conclusions. Finally, the sixth part comprised relevant reference list.

\section{Theoretical model}

Theoretical relation between the real exchange rate and real interest rate differential has been derived looking up to Byrne and Nagayasu (2010) by combining two basic building blocks: (a) uncovered interest rate parity (UIP) and 
Petrović P.: Testing of real exchange rate - real interest rate differential relationship...

(b) Fisher equation. To this end, the real exchange rate can be formulated as (Byrne \& Nagayasu, 2010, p. 139):

$q_{t}=s_{t}+p_{t}^{*}-p_{t}$

where $s_{t}, p_{t}{ }^{*}, p_{t}$ stand for natural logarithms of the nominal spot exchange rate (number of domestic currency units per foreign currency unit - $S$ ), level of prices abroad $\left(P^{*}\right)$ and level of prices in the home country $(P)$, respectively. The first building block of our model is UIP according to which in the conditions of free capital movement and perfect substitutability of domestic and foreign assets the expected changes in nominal spot exchange rate will be equal to nominal interest rate differential. If the investors are aversive towards the risk, it should be necessary to include risk premium as well, which can be formalised as:

$$
\frac{E_{t} S_{t+1}}{S_{t}}=\frac{\left(1+I_{t}\right)}{\left(1+I_{t}^{*}\right)}+u_{t},
$$

where $E_{t} S_{t+1}$ stands for current period expectations of the next period nominal spot exchange rate, $I_{t}$ and $I_{t}^{*}$ stand for the period $t$ domestic and foreign nominal interest rates pertaining to the period between $t$ and $t+1$ and $u_{t}$ stands for the exchange risk premium. Using the shortened logarithm notation, equation (2) can be re-formulated in the following way (Byrne \& Nagayasu, 2010, p. 140):

$$
E_{t} s_{t+1}-s_{t}=i_{t}-i_{t}^{*}+u_{t}
$$

where $i_{t}$ and $i_{t}^{*}$ represent $\ln \left(1+l_{t}\right)$ and $\ln \left(1+l_{t}^{*}\right)$, respectively. Replacing the expected nominal spot exchange rate expressed through equation (1) in equation (3), the following is obtained (Byrne \& Nagayasu, 2010, p. 140):

$$
E_{t} q_{t+1}-E_{t} p_{t+1}^{*}+E_{t} p_{t+1}-s_{t}=i_{t}-i_{t}^{*}+u_{t} \text {. }
$$

The second building block, as already stressed, is the Fisher equation, i.e.:

$$
\left(1+R_{t}\right)=\frac{\left(1+I_{t}\right)}{E_{t} \Pi_{t+1}},
$$

or in logarithm form for the home and foreign country:

$$
\begin{aligned}
& r_{t}=i_{t}-E_{t} \pi_{t+1}, \\
& r_{t}^{*}=i_{t}^{*}-E_{t} \pi_{t+1}^{*},
\end{aligned}
$$

where $R_{t}$ and $E_{t} \Pi_{t+1}$ respectively denote ex-ante 1-period real interest rate and period $t$ expected inflation index for one period ahead, while $r_{t}$ and $E_{t} \Pi_{t+1}\left(r_{t}^{*}\right.$ 
Petrović P.: Testing of real exchange rate - real interest rate differential relationship...

and $\left.E_{t} \pi^{*}{ }_{t+1}\right)$ denote $\ln \left(1+R_{t}\right)$ and $\ln \left(E_{t} \Pi_{t+1}\right)\left(\ln \left(1+R_{t}^{*}\right)\right.$ and $\left.\ln \left(E_{t} \Pi^{*}{ }_{t+1}\right)\right)$. The expected inflation index in the home and foreign country in period $t$ for one period ahead can be shown as (Byrne \& Nagayasu, 2010, p. 140):

$$
\begin{aligned}
& E_{t} \Pi_{t+1}=\frac{E_{t} P_{t+1}}{P_{t}}, \\
& E_{t} \Pi_{t+1}^{*}=\frac{E_{t} P_{t+1}^{*}}{P_{t}^{*}},
\end{aligned}
$$

i.e. in logarithm form:

$$
\begin{aligned}
& E_{t} \pi_{t+1}=E_{t} p_{t+1}-p_{t}, \\
& E_{t} \pi_{t+1}^{*}=E_{t} p_{t+1}^{*}-p_{t}^{*} .
\end{aligned}
$$

Finally, by combining both building blocks, i.e. by replacing equations (6), (7), (10) and (11) in equation (4), the following is obtained (Byrne \& Nagayasu, 2010, p. 140):

$E_{t} q_{t+1}-\left(E_{t} \pi_{t+1}^{*}+p_{t}^{*}\right)+\left(E_{t} \pi_{t+1}+p_{t}\right)-s_{t}=\left(r_{t}+E_{t} \pi_{t+1}\right)-\left(r_{t}^{*}+E_{t} \pi_{t+1}^{*}\right)+u_{t}$,

which after further rearranging gives (Byrne \& Nagayasu, 2010, p. 140):

$$
E_{t} q_{t+1}-p_{t}^{*}+p_{t}-s_{t}=r_{t}-r_{t}^{*}+u_{t}
$$

i.e.:

$E_{t} q_{t+1}-q_{t}=r_{t}-r_{t}^{*}+u_{t}$

$q_{t}=E_{t} q_{t+1}-r_{t}+r_{t}^{*}+u_{t}$

Equation (14) can be re-formulated as:

$\ln \left(\frac{E_{t} Q_{t+1}}{Q_{t}}\right)=\ln \left(\frac{1+R}{1+R^{*}}\right)+u_{t}$,

where:

$$
\begin{aligned}
& E_{t} Q_{t+1}=e^{E_{t} q_{t+1}}, \\
& Q_{t}=e^{q_{t}} .
\end{aligned}
$$


Petrović P.: Testing of real exchange rate - real interest rate differential relationship...

Equation (16) served as theoretical basis for testing of empirical sustainability of the real exchange rate - real interest rate differential relationship.

\section{Data}

During the research, logarithm transformation of time series was used pertaining to the period between January 2007 and May 2012. The first series - natural logarithm of the RSD/EUR real exchange rate index (left side of equation 16) was calculated by applying realised values of the nominal spot exchange rate and consumer prices indexes in Serbia and EMU. The second series natural logarithm of real interest rate differential (first summand on the right side of equation 16) was obtained by using weighted nominal interest rates at annual level and annual consumer prices index. In case of Serbia, banking interest rates for loans (new business) approved to households (including non-profit institutions serving households) and non-financial corporations were used, while for EMU interest rates that resident monetary financial institutions (MFIs, i.e. "credit institutions") apply to euro-denominated loans (new business) by households (including non-profit institutions serving households) and non-financial corporations which are residents of the euro area were used. In addition, realised consumer price index was applied in both cases.

The list of variables and sources of data are shown in the table below, and all detailed information about the way of their construction are available at request.

Table 1. Variables we used during the empirical research

\begin{tabular}{|c|c|c|}
\hline Variable & Label & Source \\
\hline $\begin{array}{l}\text { The natural } \\
\text { logarithm of the } \\
\text { real exchange } \\
\text { rate index } \\
\text { (RSD / EUR) }\end{array}$ & Inrer & $\begin{array}{c}\text { Author's calculation based on data } \\
\text { downloaded from } \\
\text { http://www.nbs.rs, } \\
\text { http://webrzs.stat.gov.rs and } \\
\text { http://epp.eurostat.ec.europa.eu. }\end{array}$ \\
\hline $\begin{array}{l}\text { The natural } \\
\text { logarithm of the } \\
\text { real interest } \\
\text { rate differential } \\
\text { between Serbia } \\
\text { and EMU }\end{array}$ & Inrird & $\begin{array}{c}\text { Author's calculation based on data } \\
\text { downloaded from } \\
\text { http://www.nbs.rs, } \\
\text { http://webrzs.stat.gov.rs and, } \\
\text { http://www.ecb.int/home/html/index.en. } \\
\text { html and } \\
\text { http://epp.eurostat.ec.europa.eu. }\end{array}$ \\
\hline
\end{tabular}

Source: Author 
Petrović P.: Testing of real exchange rate - real interest rate differential relationship...

\section{Results of empirical Research}

Testing of the baseline hypothesis was applied as a strat to show the presence of empirical grounds for relation (16) with visual examination of time series (Fig. 1) and testing of their nonstationarity. The results obtained through use of Augmented Dickey-Fuller (ADF), Dickey-Fuller GLS (ERS or DF-GLS), Phillips-Perron (PP) and Kwiatkowski-Phillips-Schmidt-Shin (KPSS) unit root tests prevailingly showed that the observed time series are I(1) stochastic processes.

Figure 1. The natural logarithm of the real exchange rate index, natural logarithm of the real interest rate differential and their first differences

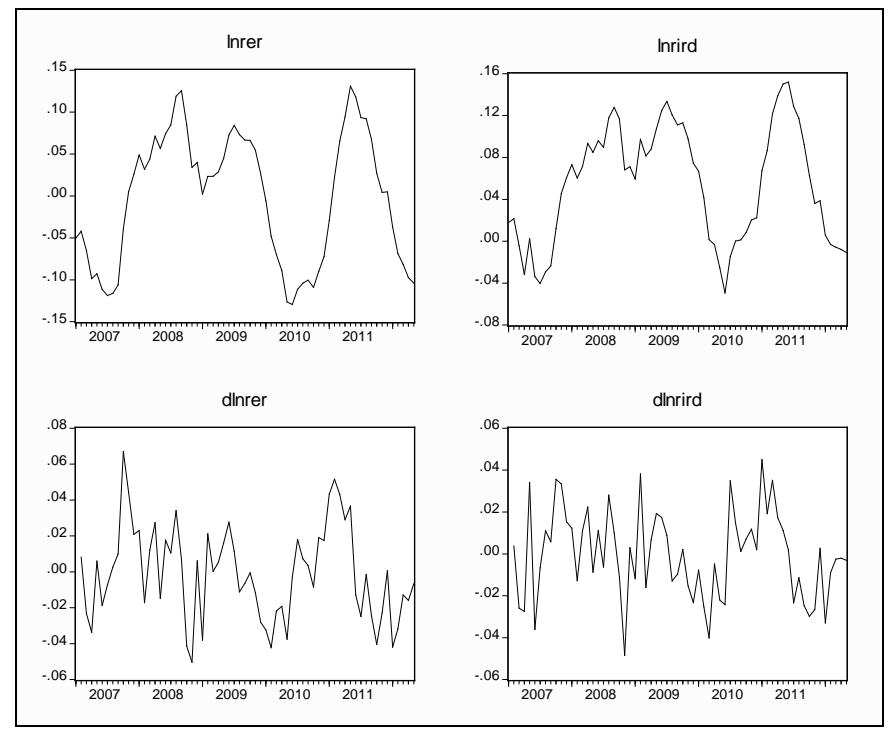

Source: Author

Nonstationarity of time series suggests the application of cointegration procedure in the rest of the analysis. Estimation of the first cointegration equation applying the ordinary least squares method (OLS) resulted in the following regression:

$\ln$ rer $=-0.076+1.35 \ln$ rird .

$$
\text { (0.0037) (0.048) }
$$

$\left(E G=-2.18 ; C V_{10 \%}=-3,11\right)$ 
Petrović P.: Testing of real exchange rate - real interest rate differential relationship...

Figure 2. Actual and fitted value of Inrer-cointegration equation (19)

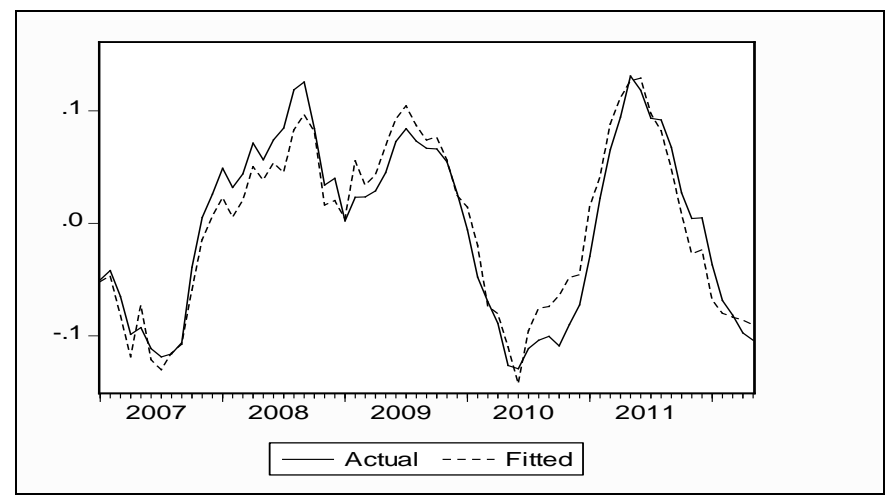

Source: Author

Despite the fact that fitted value of the real exchange rate index well describes dynamics of its actual value (Fig. 2) application of Engle-Granger (EG) cointegration test (values given in brackets below standard errors) shows that null hypothesis about residuals nonstationarity even at $10 \%$ significance level cannot be rejected, which is confirmed by visual appearance of residual series (Fig. 3).

Figure 3. Residual from cointegration equation (19)

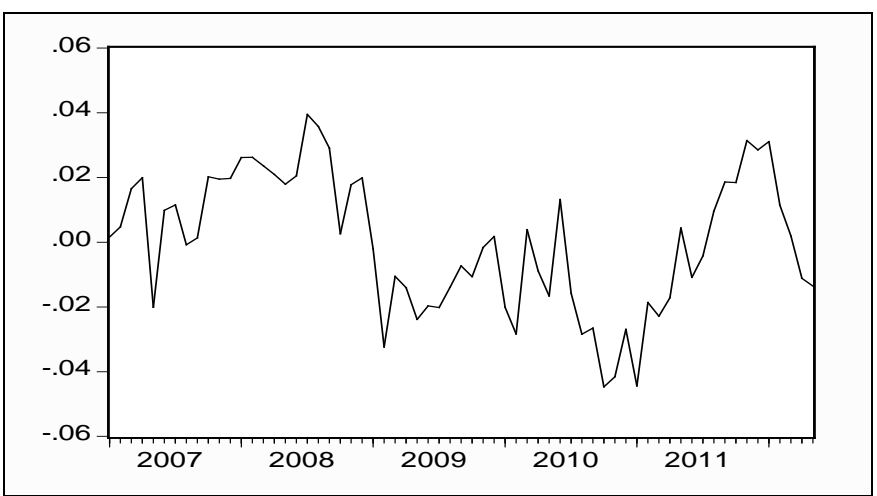

Source: Author

Extension of cointegration equation (19) by including a linear time trend gives very similar results:

$\ln$ rer $=-0.066-0.0003 t+1.36 \ln$ rird. 
Petrović P.: Testing of real exchange rate - real interest rate differential relationship...

$$
(0.005) \quad(0.0001) \quad(0.046)
$$

$\left(E G=-2.76 ; C V_{10 \%}=-3,62\right)$

Figure 4. Actual and fitted value of Inrer-cointegration equation (20)

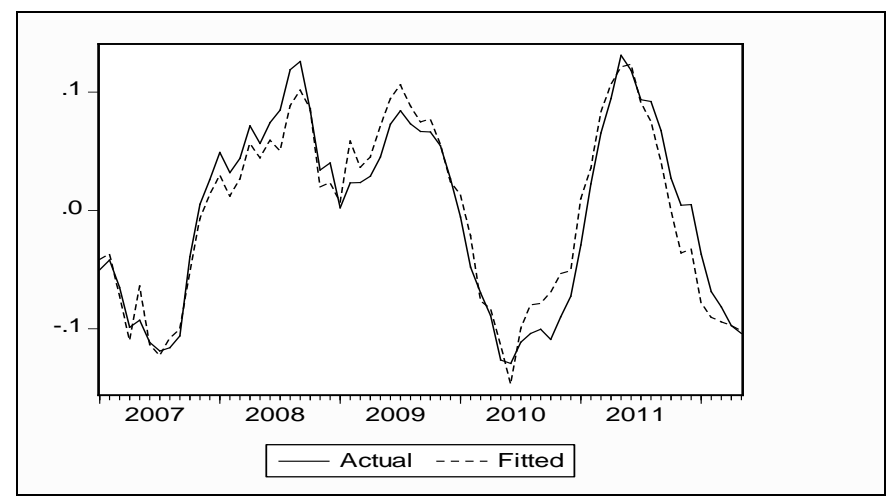

Source: Author

In other words, although there is a high level of compatibility between the fitted and actual values of the real exchange rate index (Fig. 4), application of a 2 step procedure of EG test indicates the fact that real exchange rate index and real interest rate differential are not cointegrated series, i.e. that there is no long-run equilibrium relation between them. Such testing results are compatible with cointegration equation (20) residual series movement (Fig. 5), which doubtlessly reveals that this is a nonstationary series.

Figure 5. Residual from cointegration equation (20)

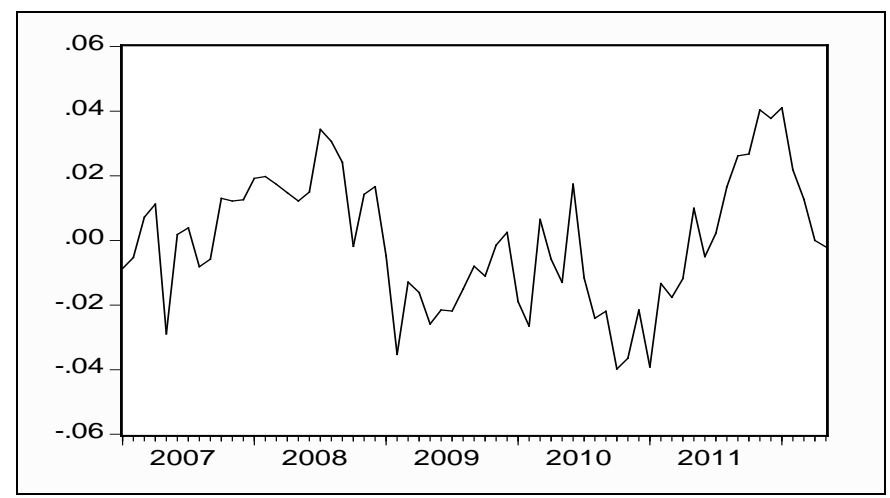

Source: Author 
Petrović P.: Testing of real exchange rate - real interest rate differential relationship...

Alternative testing applied through Johansen procedure also confirmed that real exchange rate index and real interest rate differential are not cointegrated series. Testing has been conducted based on the initial VAR model of the second order with a constant as deterministic component. Testing of statistical properties of the initial VAR model shows that the model is stable, that residuals are normally distributed and homoscedastic, and that they are not autocorrelated. Application of this procedure implies the following cointegration relation:

$\ln$ rer $=-0.066+1.15 \ln$ rird .

(0.012) (0.149)

(Trace $\left.=14.50 ; \mathrm{CV}_{5 \%}=20.26\right)$

(Max-Eigen= 7.82; $\left.\mathrm{CV}_{5 \%}=15.89\right)$

Figure 6. Actual and fitted value of Inrer-cointegration equation (21)

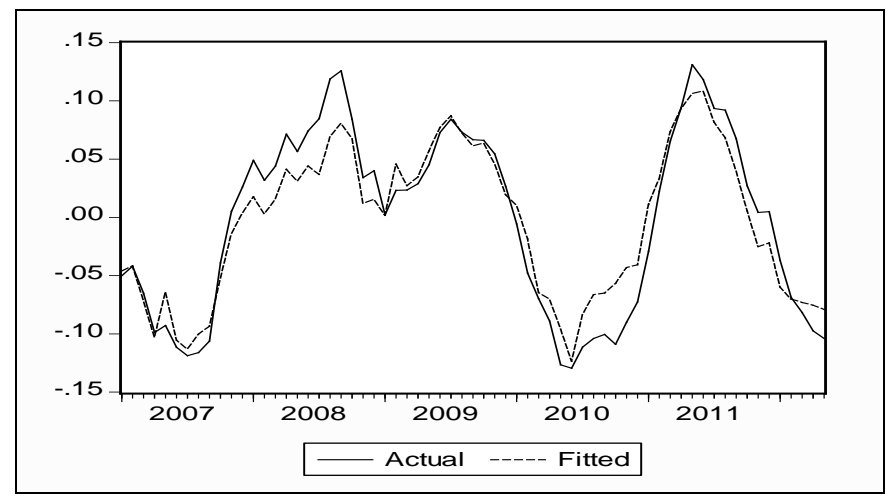

Source: Author

The fact that real exchange rate index and real interest rate differential are not cointegrated at $5 \%$ significance level indicated by both test statistics (MaxEigenvalue Statistic and Trace Statistic), is confirmed by visual appearance of the residual series (Fig. 7). 
Petrović P.: Testing of real exchange rate - real interest rate differential relationship...

Figure 7. Residual from cointegration equation (21)

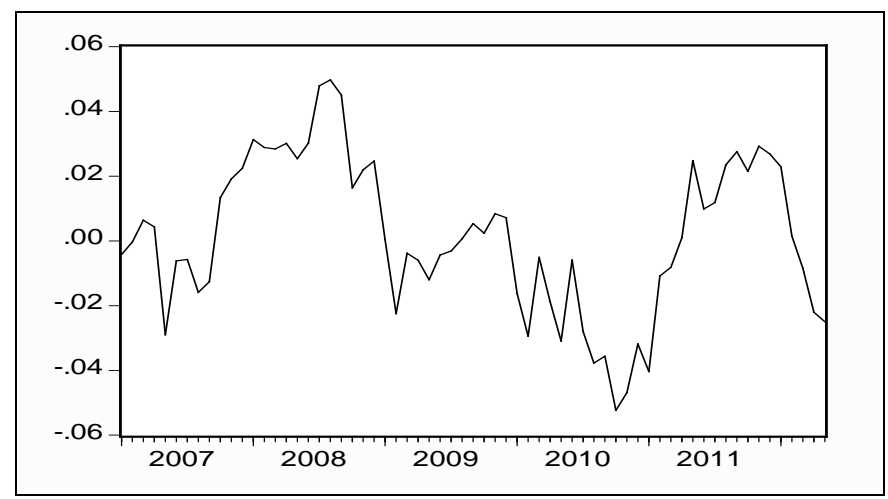

Source: Author

Based on all presented results obtained by applying two usual cointegration tests, it can be concluded that there is no long-run equilibrium relation between the real exchange rate index and real interest rate differential in SerbiaEMU case. Taking into account such results, it is clearly obvious that our paper can join a range of studies (Campbell \& Clarida, 1987; Meese \& Rogoff, 1988; Edison \& Pauls, 1991; Clarida \& Gali, 1994; Engel \& Kim, 1999; and partially Chortareas \& Driver, 2001 and Edison \& Melick, 1999), which all have in common the lack of empirical confirmation for the real exchange rate real interest rate differential relationship.

\section{Conclusion}

Taking into account the outcome of our study, the baseline hypothesis that empirical data confirms the presence of real exchange rate - real interest rate differential connection in Serbia-EMU case was rejected, due to which it cannot be concluded that there are no proofs that the observed relation is a pattern for explanation of long-term RSD/EUR real exchange rate dynamics. This conclusion has been achieved by applying the time series cointegration concept, based on Engle-Granger and Johansen test, for the period between January 2007 and May 2012. Use of this methodological framework did not enable us to reveal the existence of long-run equilibrium (cointegration) relation between real exchange rate and real interest rate differential. In other words, empirical data do not support the thesis on relation between these two variables. Key contribution of our study is reflected through the fact that it (with Petrović, 2013) is the only one empirical analysis known to us which per- 
Petrović P.: Testing of real exchange rate - real interest rate differential relationship...

tains to theoretical connection between real exchange rate and real interest rate differential in Serbia-EMU case. Taking this fact into account, our paper could serve as inspiration for future researches, but also for further development and improvement of the methodological framework. Key weakness of this study is the use of still insufficiently long time series and data about weighted interest rates which is not of highest quality. Actually, high quality data about weighted interest rates has been available only from September 2010, while unofficial data of the National Bank of Serbia had been used for the previous period, which actually is the best possible approximation of weighted interest rates intended for the central bank internal needs. In addition, according to methodology applied by Byrne and Nagayasu (2010), it would also be purposeful to try to apply Saikkonen and Lütkepohl (2000) Trace tests in the event that existence of structural breaks turns out to be true. Recommendations that could be provided provide for future researches pertain to elimination of all weaknesses we have just mentioned. Hence, they would pertain to implementation of analysis based on longer time series, maximally quality data and cointegration tests which are resistant to the existence of structural breaks. In addition, it would be interesting to test empirically the connection between real exchange rate and real interest rate differential relying on different mathematical models and methodological frameworks looking up to cited papers. Finally, we think that it would be useful that focus of research is shifted from the Serbia - EMU case to panels of differently grouped and categorised countries in order to obtain wider picture of the observed connection empirical basis.

\section{References}

Baxter, M. (1994). Real exchange rates and real interest differentials: Have we missed the business-cycle relationship.Journal of Monetary Economics, 33(1), 5-37. doi:10.1016/0304-3932(94)90012-4

Byrne, P.J., \& Nagayasu, J. (2010). Structural breaks in the real exchange rate and real interest rate relationship. Global Finance Journal, 21, 138-151. doi:10.1016/j.gfj.2010.06.002

Campbell, Y.J., \& Clarida, H.R. (1987). The dollar and real interest rates. NBER Working Paper, 2151, Retrieved from http://dash.harvard.edu/bitstream/handle/1/3221495/campbell_dollarrealinterest. pdf?sequence=2 doi:10.1016/0167-2231(87)90005-4

Chortareas, E. G., \& Driver, L. R. (2001). PPP and the real exchange rate-real interest rate differential puzzle revisited: Evidence from non-stationary panel data. Bank of England Working Paper No. 138. Retrieved from http://www.bankofengland.co.uk/publications/Pages/workingpapers/2001/wp138. $\underline{\operatorname{aspx}}$ 
Petrović P.: Testing of real exchange rate - real interest rate differential relationship...

Clarida, R., \& Gali, J. (1994). Sources of real exchange rate fluctuations: How important are nominal shocks? NBER Working Paper No. 4658. Retrieved from http://www.nber.org/papers/w4658.pdf?new window=1

Dornbusch, R. (1976). Expectations and Exchange Rate Dynamics. Journal of Political Economy, 84(6), 1161-1176. doi:10.1086/260506

Edison, J. H., \& Melick, R. W. (1999). Alternative approaches to real exchange rates and real interest rates: Three up and three down. International Journal of Finance and Economics, (4), 93-111.

Edison, J. H., \& Pauls, D. B. (1991). A re-assessment of the relationship between real exchange rates and real interest rates: 1974-1990. IFDP Working Paper No. 408. Retrieved from http://www.federalreserve.gov/pubs/ifdp/1991/408/ifdp408.pdf

Engel, C., \& Kim, C. (1999). The Long-Run U.S./U.K. Real Exchange Rate. Journal of Money, Credit and Banking, 31(3), 335-356. doi:10.2307/2601115

Frenkel, J.A. (1976). A Monetary Approach to the Exchange Rate: Doctrinal Aspects and Empirical Evidence. Scandinavian Journal of Economics, 78(2), 200-224. doi:10.2307/3439924

Kanas, A. (2005). Regime linkages in the US/UK real exchange rate-real interest differential relation. Journal of International Money and Finance, 24, 257-274. doi:10.1016/j.jimonfin.2004.12.006

MacDonald, R., \& Nagayasu, J. (1999). The long-run relationship between real exchange rates and real interest rate differentials: A panel study. IMF Working Paper No. 37. Retrieved from http://www.imf.org/external/pubs/ft/wp/1999/wp9937.pdf

Meese, R., \& Rogoff, K. (1988). Was it real? The exchange rate-interest differential relation over the modern floating-rate period. The Journal of Finance, 43(4), 933948.

Nakagawa, H. (2002). Real exchange rates and real interest differentials: Implications of nonlinear adjustment in real exchange rates. Journal of Monetary Economics, 49, 629-649.

Petrović, P. (2013). Testing of empirical grounds for theoretical models of real exchange rate: Research of real exchange rate between RSD and Euro. Industrija, 41(1), 99-115. doi:10.5937/industrija41-3522

Saikkonen, P., \& Lütkepohl, H. (2000). Testing for the cointegrating rank of a VAR process with structural shifts. Journal of Business \& Economic Statistics, 18(4), 451-464. 